\title{
APPLICATION OF DIFFERENT PROBING METHODS FOR REMOTE ESTIMATION OF PASTURE FERTILITY
}

\author{
Vladimir Trukhachev, Serhii Oliinyk, Tatyana Lesnyak, Nikolay Zlydnev \\ Stavropol State Agrarian University, Russia \\ inf@stgau.ru, soliynik60@gmail.com, tatastav026@gmail.com,nz-kormlenec@yandex.ru
}

\begin{abstract}
The study of agricultural areas is one of the most effective areas for using remote monitoring using unmanned aerial vehicles and portable devices. When using photographs and photographs obtained by using technological equipment of unmanned aerial vehicles, it is possible to resolve issues that include both the task of quickly obtaining information about the composition and condition of agricultural and pasture crops, potential yield, diseases and damage to crops by pests, and the task of inventorying land resources, estimating biomass studying the dynamics of agricultural land use. However, the obtained data on the state of vegetation must be compared with other methods of remote monitoring and routine laboratory studies, which allows obtaining objective data. Remote assessment of pasture vegetation was carried out using a special camera to calculate the NDVI (Normalized Difference Vegetation Index), which was installed on an unmanned aerial vehicle. At the same time, the dynamics of the NDVI index using a portable manual nitrogen sensor was studied in the same pasture areas. The results of monitoring the vegetative index on pasture plots were compared with the results of chemical analysis of plant feeds, the correlation index depended on the level of precipitation and the period of plant vegetation and was in the range of 0.55-0.88. The research results allow us to predict the dynamics of changes in the load of the pasture animals (sheep) during different periods of plant vegetation.
\end{abstract}

Keywords: remote sensing, unmanned aerial vehicles, portable nitrogen sensor, vegetation index, pastures, sheep.

\section{Introduction}

Remote monitoring is becoming increasingly attractive for modern agricultural business, since the possibility of obtaining uniform information on the state of agricultural territories and crops is becoming extremely important for making prompt business decisions.

The range of issues that can be resolved using images taken from satellites and images from the technological equipment of unmanned aerial vehicles includes the tasks of quickly obtaining information about the composition and condition of crops, potential yields, diseases and damage to crops by pests, as well as land inventory tasks, biomass estimates, study of the dynamics of agricultural land usage. In their studies J. D. Rotz, A. O. Abaye, et al. established the potential for a semi-automatic classification of ground digital photographs to evaluate productive soil cover. The result was $83.7 \%$ similarity with soil cover maps [1].

The monitoring system for various abovegroundobjects, including pastures and herds, using aircraft, aerostat tools, satellites and satellite systems is called the aerospace monitoring method, which is divided into four main categories [2;3].

Remote monitoring is a combination of aviation and space monitoring. This concept can include tracking the environment using instruments installed in remote places of the Earth, for example, in the mountains or on the Far North, the readings of which are transmitted to observation centers using long-range information transmission methods (via radio, wires, etc.) .

Airborne monitoring is carried out from aircraft, helicopters and other aircraft (including balloons, aerostats, quadrocopters, unmanned aerial vehicles, etc.), which do not rise to space heights. Space monitoring (Satellite monitoring) is monitoring with the help of space-based surveillance tools, for example, from satellites or probes $[4 ; 5]$.

Aerospace monitoring (cartographic and aerospace) is the operational tracking and control of the state of the environment and its individual components as a result of remote sensing and mapping. The advantages of aerospace monitoring are multiscale and multi-temporal [6].

The determination of the vegetation index (NDVI - Normalized Difference Vegetation Index), based on spectral measurements in the red and infrared regions of the spectrum, has become one of the directionsfor remote monitoring of the degree of accumulation of plant biomass in pasture plots and agricultural fields. 
The use of special technological equipment installed on space satellites or unmanned aerial vehicles makes it possible to obtain photographs, the decoding of which allows the calculation of the NDVI index. As numerous works of domestic and foreign authors have shown, the maximum absorption of solar radiation by chlorophyll of higher vascular plants is in the red region of the spectrum $(0.6-0.7 \mu \mathrm{m})$, and the region of maximum reflection of leaf cell structures is in the infrared region $(0.7-1.0 \mu \mathrm{m})$. Thus, the vegetative index NDVI allows us to characterize the amount of photosynthetically active biomass $[7 ; 8]$.

D. Terrance Booth and Samuel E. Cox propose using the SAMPLEPOINT software with the function of spot classification of digital images, which saves time and costs relative to conventional field measurements [9].

In the steppe regions of southern Russia, one of the most common types of agricultural activity is pastoralism, including beef cattle breeding and sheep breeding, and sheep breeding is dominant, since grazing sheep on natural pastures allows to obtain high-quality mutton, the demand for which has been recently significantlyincreased.

The practice of industrial sheep breeding in the area ofintensive agriculture shows that the branches of crop production and grazing sheep can and do complement each other perfectly. One of the problems is the timely selection of the optimal territory for grazing sheep, in combination with the necessary complex of field work. At the same time, the use of various methods of remote monitoring allows to varying degrees to assess the state of biomass of forage grasses and plants and make an optimized decision in the direction of industrial use of agricultural territories [10].

The aim of our research was to analyze the effectiveness of the use of different sensing methods for remote assessment of pasture fertility.

\section{Materials and methods}

In accordance with the purpose of the work, the research objectives were determined: to determine the vegetation index NDVI in the studied areas; to carry out an agrochemical analysis of soils depending on the vegetation index; build a digital map of the pasture with a vegetative index in arid places; determine the nutritional value of fodder plants by the seasons of the year; to establish the productive qualities of pasture animals in the studied areas; determine the significance of remote monitoring in grazing.

Researches were carried out in the North Caucasus region of the Russian Federation in the conditions of a merino sheep breeding farm. The grazing period was from April to August. The stress on pastures was 10 animals per 1 ha. To assess the growth rates of 3-month age pedigree lambs, animals of the control group $(n=20)$ were weighed, while live weight is taken into account, the average daily gain in live weight is calculated by the standard zootechnical method.

Remote monitoring includes the use of unmanned aerial vehicles (UAVs) of the middle class with a take-off weight of up to $100 \mathrm{~kg}$ and a range of 10 to $100 \mathrm{~km}$, as well as using data services received from space satellites. On-board equipment, in addition to basic equipment, as well as a digital camera and an infrared camera, which allows the calculation of the vegetation index NDVI, are used.

The groups of animals weregrazed on pastureswith leguminous-cereal plants (25:75\%): onobrich, alfalfa, festucapratensis, loliumperenne.

To evaluate and compare the effectiveness of various methods of remote monitoring, a chemical analysis of pasture feed was observed. The chemical composition of feed (crude protein, crude fiber, crude fat, crude ash, calcium, phosphorus, amino acid composition) and humidity were determined in the equipment of INGOS (Czech Republic), FIBRETHERM (Germany), VELP SCIENTIFICA (Italy) in the laboratories of the Scientific and Technical Center "Feed and Metabolism" (accreditation certificate No.ROSS RU.0001.21PU12 of 10.28.2014).

\section{Results and Discussion}

Often, especially when the supply of feed is running out, cattle are driven out to pasture in early spring, although the grass has not yet grownand the soil is waterlogged. This is very harmful because of the strong trampling of the grass stand. 
According to Mikhailenko I.M, in wet years, discretepasture plots can be used for haying. In this case, the pasture receives rest, harmful plants that are not eaten by animals are mowed, thereby weakening their development in the future $[11 ; 12]$.

Movingof livestock to pasture should be preceded by a survey of pasture lands, distribution of plots according to herds, drawing up a calendar use plan.

One of the main reasons leading to overgrazing of pastures is violation of the ratio between the number of animals and feed supply.

A combination of agrochemical soil analysis methods and remote research methods allowed us to establish that an increase in the gross yield of organic biomass is in positive correlation with the development of the humus layer of the soil and a higher concentration of nutrients - phosphorus and potassium (Table 1):

Agrochemical analysis of the soil

Table 1

\begin{tabular}{|l|c|c|}
\hline \multicolumn{1}{|c|}{ Soilindicator } & NDVI $=\mathbf{0 . 4 5}$ & NDVI $=\mathbf{0 . 5 5}$ \\
\hline $\mathrm{P}_{2} 0_{5}, \mathrm{mg} \%$ & 14.0 & 10.0 \\
\hline $\mathrm{K}_{2} 0, \mathrm{mg} \%$ & 499.0 & 395.0 \\
\hline $\mathrm{pH}$ & 7.9 & 7.2 \\
\hline Humus, \% & 3.6 & 2.8 \\
\hline
\end{tabular}

Agrochemical analysis of the soil showed that the plot with a vegetation index of 0.45 has a better composition than the plot where the vegetation index was 0.55 .

In a study by Bernardi, A. et al., the relationship between the vegetation index and the physicochemical state of the soil, as well as the use of satellite systems to assess pasture fertility, was identified [13].

The use of digital aerospace technologies made it possible to obtain a fundamentally new pasture map - a digital one. The histogram shows an example of the distribution, taking into account areal coefficients, various fragments of the territory of the pasture plot, in the specific percentage ratio - the area of plots with different characteristics of the NDVI index, which allows remote prognostic assessment of the presence of plant biomass in the pasture plot (Fig. 1).

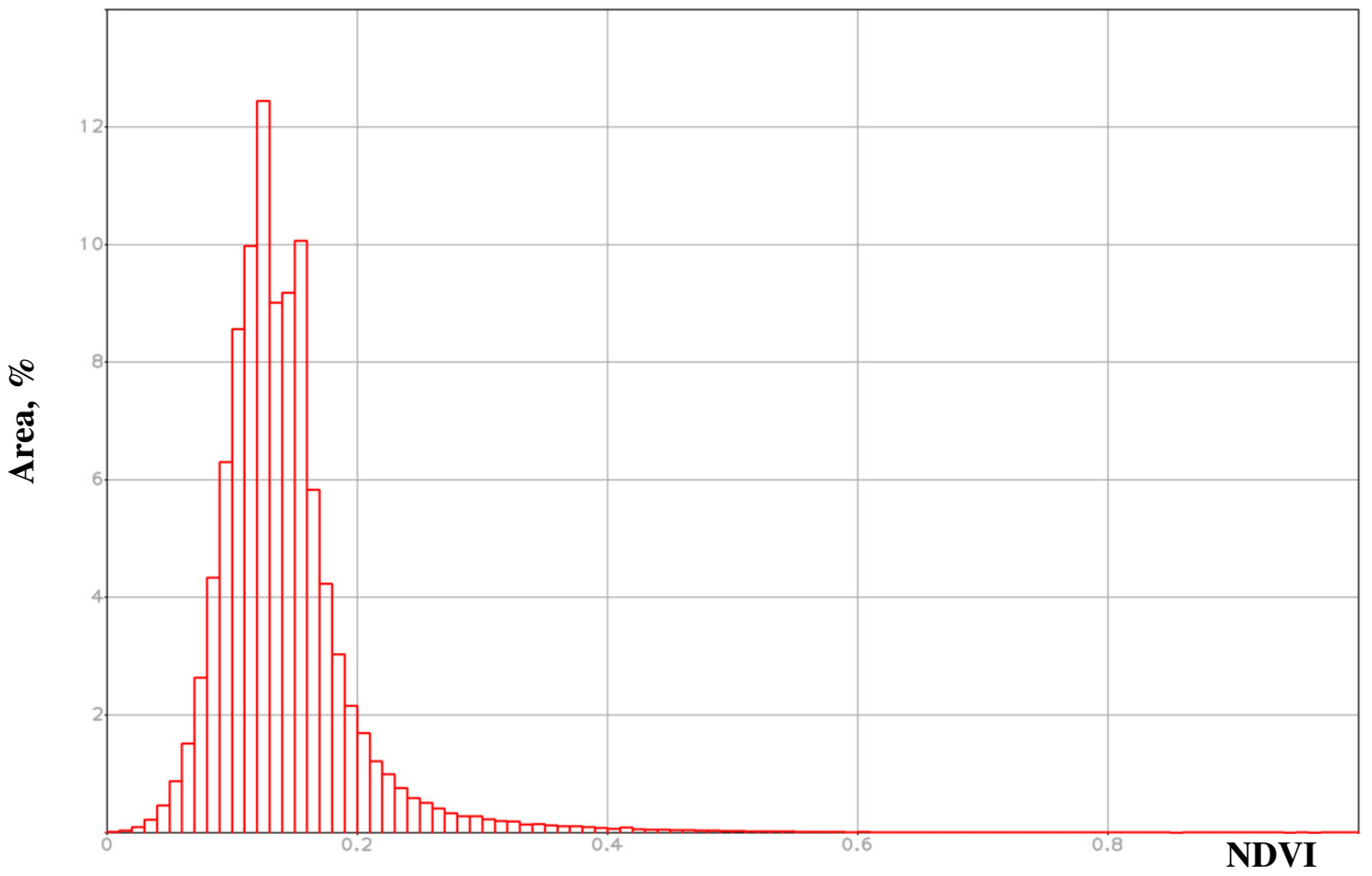

Fig. 1. Digital map of pasture - vegetation index (NDVI) of pasture land in arid places 
The methodological approaches we developed for organizing pastoral livestock using digital aerospace remote monitoring technologies, make it possible to take a fundamentally different approach to the organization of a system for raising pasture animals in modern agro-industrial production, which includes the crop and livestock sectors.

The nutritional value of pasture feed is shown in Figure 2.

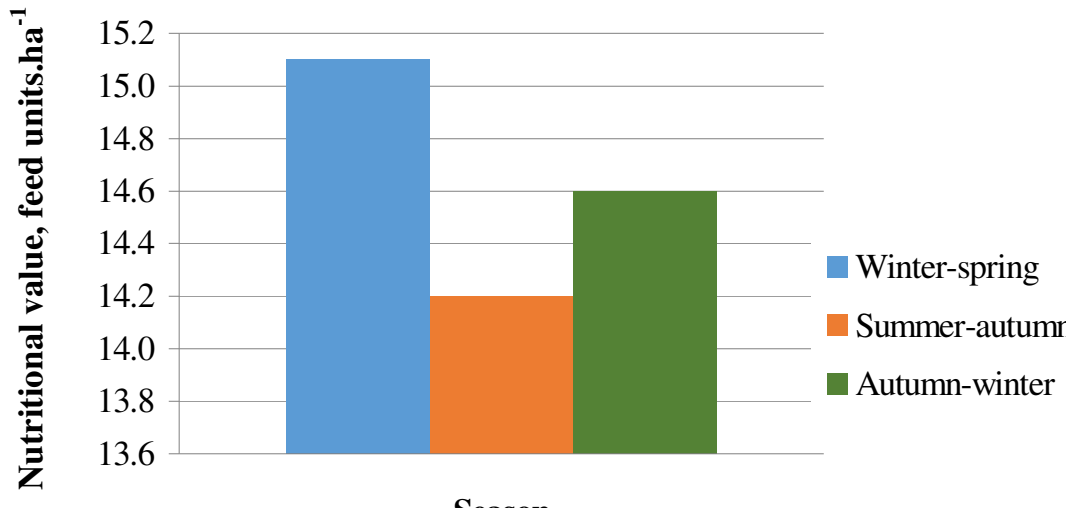

Season

Fig. 2. Nutritional value, feed units $\cdot \mathbf{h a}^{-1}$

After evaluating the nutritional value of fodder plants using remote sensing methods, it was found that in the winter-spring period the nutritional value of fodder plants is $6.3 \%$ and $3.4 \%$ higher than in the summer-autumn and autumn-winter periods, respectively.

Evaluation of productivity indicators of technological groups of pasture animals obtained using zootechnical metering in pasture areas where remote methods of aerospace monitoring are used, depending on the season, are presented in Table 2.

Table 2

Indicators of productive qualities of pasture animals by season

\begin{tabular}{|c|c|c|c|c|}
\hline Indicator & Winter & Spring & Summer & Autumn \\
\hline Live weight, kg & 33.9 & 46.5 & 60.5 & 77.8 \\
\hline Average daily gain, g & 115.4 & 165.4 & 163.0 & 151.5 \\
\hline Feed intake, feed units & 7.4 & 9.7 & 10.7 & 11.0 \\
\hline
\end{tabular}

The analysis of indicators of productive qualities of pasture animals during the year showed that the live weight, average daily gain and intake of feed units were at the standard level. The group of animals that were assigned to the plots without monitoring the nutritional value of the forage land had a live weight of $1.2 \%$ lower.

Remote monitoring of the distribution of plant debris in pasture plots and areas for grazing animals allows us to determine the most optimal zones with a maximum yield of plant biomass, which is converted to an increase in biomass of pasture animals. In their studies, S. M. Punalekar, A. Verhoef also talk about the need to monitor rangelands in order to timely influence their productivity, which will further improve the efficiency of introducing pasture livestock [14].

The economic efficiency of the use of remote aerospace monitoring to improve the biological productivity of pasture territories will be determined by the effectiveness of a set of measures:

- aerospace monitoring of energy and nutritional value of pasture feed;

- construction of predictive mathematical models of effective livestock husbandry;

- searching for additional sources of water resources;

- determination of periods of optimal use of natural and cultural pastures.

The prospect of further research could be development of a detailed technological map of the production use of agricultural land, taking into account crop rotation, assessing the nutritional value of crop residues, production tasks for the production of various products of the livestock industry. 


\section{Conclusions}

1. Introduction of modern digital aerospace technologies is the most important guarantee of successful and competitive development of national grazing animal husbandry.

2. Introduction of a remote aerospace monitoring system will contribute to the rational use of rangelands, which will avoid degradation of rangelands and additionally receive $1-1.2 \mathrm{~kg}$ of feed units per 1 ha.

\section{Acknowledgment}

The work was supported by the Ministry of Education and Science of the Russian Federation; electronic budget agreement number 075-02-208-920; internal agreement number 14.613.21.0081; 14.613.21.0081 and the Russian Ministry of Education dated November 22, 2017; unique work identifier: RFMEFI61317X0081 R\&D registration number AAAA- A18-118040390089-9.

\section{References}

[1] Rotz J. D., Abaye A. O., Wynne R. H., Rayburn E. B., Scaglia G., and Phillips R. D. Classification of Digital Photography for Measuring Productive Ground Cover // Rangeland Ecology and Management. 2008. No. 61(2), pp. 245-248

[2] Antonov V. N., Sweet L. A. 2009. Monitoring of the state of crops and forecasting the yield of spring wheat according to remote sensing data (Antonov V. N., Sladkikh L. A. Monitoring sostoyaniya posevov I prognozirovaniye urozhaynosti yarovoy pshenitsy po dannym DZZ) // Geomatics. 2009. No. 4. pp. 50-53.

[3] Bartalev S. A. Classification of certain types of agricultural crops in the southern regions of Russia according to MODIS satellite data (Bartalev S. A. Klassifikatsiya nekotorykh tipov sel'skokhozyaystvennykh posevov $\mathrm{v}$ yuzhnykh regionakh Rossii po sputnikovym dannym MODIS) // Modern problems of remote sensing of the Earth from space. 2006. No. 3. pp. 68-75.

[4] Zhelezova S. V., Ananiev A. A., Vyunov M. V., Berezovsky E. V. Monitoring of winter wheat crops using unmanned aerial photography and an optical sensor GreenSeeker RT200 // Bulletin of the Orenburg State University. 2016. No. 6. pp. 56-61.

[5] Kashkin V. B., Sukhinin A. I. Digital processing of aerospace images. - Krasnoyarsk: IPK SFU, 2008. [online] [12.11.2019]. Available at: http://files.lib.sfu-kras.ru/ebibl/umkd/54/u_course.pdf

[6] Landsat Data Continuity Mission. Press Kit. - 2013 [online] [24.10.2019]. Available at: www.nasa.gov/pdf/723395main_LDCMpresskit2013-final.pdf.

[7] CrippenR.E. 1990. Calculating the Vegetation Index Faster // Remote Sensing of Environment. Vol. 34. pp. 71-73.

[8] Karaev, VV. UAVs in agriculture // Collection: Scientific works of the Gorsky State Agrarian University "Student Science for the Agro-Industrial Complex" in 2 parts. Vladikavkaz, 2016. pp. 22-26.

[9] Booth, D. T., S. E. Cox, and R. D. Berryman. Point sampling digital imagery with «sample point» // Environmental Monitoring and Assessment. 2006. pp. 97-108.

[10] Yakushev, V. P. Progressive technologies in the information support of agriculture in Russia / V. P. Yakushev // Abstracts of the International Congress of Agriculture. 2016. pp. 164-165.

[11] Mikhailenko I.M., Timoshin V.N., Malygin V.D. Making decisions on the date of harvesting feed based on data from remote sensing of the Earth and adaptable mathematical models // Modern problems of remote sensing of the earth from space. 2017.V.14. No. 2. pp. 65-79.

[12] Mikhailenko I. M., Timoshin V. N., Danilova T. N. Mathematical modeling of the soil - plant atmosphere system using perennial herbs as an example (Mikhaylenko IM, Timoshin VN, Danilova TN Matematicheskoye modelirovaniye sistemy "pochva - rasteniye - atmosfera "naprimere mnogoletnikh trav) // Reports of the Russian Academy of Agricultural Sciences. 2009. No. 4. pp. 61-64.

[13] Bernardi, A. C. de C., Grego, C. R., Andrade, R. G., Rabello, L. M., \& Inamasu, R. Y. Spatial variability of vegetation index and soil properties in an integrated crop-livestock system // RevistaBrasileira de EngenhariaAgrícola e Ambiental. 2017. No. 21(8) pp. 513-518.

[14]Punalekar S. M., Verhoef A., Quaife T. L., Humphries D., Reynolds C. K. Application of Sentinel-2A data for pasture biomass monitoring using a physically based radiative transfer model // Remote Sensing of Environment. V 2181. 2018. pp. 207-220. 